\title{
A SPORTOLÓI KIÉGÉS KÉRDŐÍV HAZAI ADAPTÁCIÓJA
}

\section{KOVÁCS KRISZTINA ${ }^{1,2}$ - BERKI TAMÁS ${ }^{3}$ - ÁGOSTON RÉKA ${ }^{4}-$ SMOHAI MÁTÉ ${ }^{4}$ - HARSÁNYI SZABOLCS GERGŐ ${ }^{4}$ - SZEMES ÁGNES ${ }^{1}$ - GYÖMBÉR NOÉMI ${ }^{1}$}

\author{
${ }^{1}$ Testnevelési Egyetem, Gazdaság- és Társadalomtudományi Intézet, Pszichológia és \\ Sportpszichológia Tanszék \\ ${ }^{2}$ Budapest Honvéd Kosárlabda Akadémia \\ ${ }^{3}$ Szegedi Tudományegyetem, Juhász Gyula Pedagógusképzô Kar, Testnevelési \\ és Sporttudományi Intézet \\ ${ }^{4}$ Károli Gáspár Református Egyetem, Pszichológiai Intézet
}

E-mail: kovacs.krisztina@tf.hu

Benyújtva: 2020. február 24. - Elfogadva: 2020. augusztus 2.

\begin{abstract}
Háttér és célkitûzések: Jelen tanulmány célja a Sportolói Kiégés Kérdốv (ABQ, Raedeke és Smith, 2001) magyar változatának pszichometriai vizsgálata, a mérôeszköz reliabilitásának és validitásának ellenôrzése. Módszer: A kérdôiv érvényességét és megbizhatóságát egy 1317 fôs kényelmi mintán ellenöriztük. A fent említett kérdôiv mellett felvételre került a Sportkörnyezet Kérdôiv (SCQ-H; Deci, 2001; Kovács, Gyömbér, F. Földi és Lénárt, megjelenés alatt), a Sportmotiváció-2 Kérdốv (SMS-2; Smohai és mtsai, 2019) és a Majdnem Tökéletes Skála rövid változata (SAPS; Reinhardt, Tóth és Rice, 2019).

Eredmények: A megerôsitô faktoranalízis az eredeti faktorstruktúrát alátámasztó eredményeket mutatott, három elkülönülő faktort kaptunk (Kimerültség; Leértékelés; Teljesitmény csökkenése). A kérdồv skáláinak belsố megbizhatósága megfelelônek bizonyult (Cronbach $\alpha$ : 0,76-0,86). Az idôbeli stabilitás vizsgálata során pozitív erốs kapcsolatot találtunk a teszt-reteszt között [Kimerültség $-r(121)=0,92, p<0,001$; Leértékelés $-r(123)=0,90, p<0,001$; Teljesítmény csökkenése $-r(123)=0,60, p<0,001]$. A konvergens validitás vizsgálata során a korábbi kutatásokkal megegyezô, gyenge-közepes korrelációkat kaptunk ( $r=$ -0,20-0,52) a sportolói kiégés három skálája és a sportmotiváció típusai, az észlelt edzôi autonómiatámogatás mértéke és a perfekcionizmus formái között.

Következtetések: A kérdỗv magyarra fordított változata pszichometriailag megfelelô méröeszköznek tekinthetô, kiváltképp serdülók körében alkalmazva.
\end{abstract}

Kulcsszavak: sportolói kiégés, autonómiatámogatás, öndeterminációs elmélet, perfekcionizmus 


\section{BEVEZETÉS}

\section{A sportolói kiégés definíciója és modelljei}

A sportolói kiégés jelenségét a 80-as években kezdték el behatóbban vizsgálni, amikor a társadalmi és tudományos érdeklôdés középpontjába került az a kérdéskör, hogy miért hagyott fel sportolói karrierjével számos, pályája csúcsán lévố elit sportoló (Hughes, 2014). A sportolói kiégéshez kapcsolódó elsô, azóta az egyik legnépszerúbb definíció Smith (1986) nevéhez fưzôdik: egy élvezetes tevékenységbôl való pszichológiai, érzelmi és fizikai visszalépés, amit a krónikus stressz válthat ki és az elégedetlenség érzetéhez vezethet. A sport területén több alternatív meghatározás is született a kiégéshez kapcsolódó jelek és tünetek pontos meghatározására. Maslach és Jackson (1984) szerint a kiégés viszont olyan komplex pszichológiai tünetegyüttes, melynek három dimenziója van: az érzelmi kimerülés, a teljesítménycsökkenés érzete és a leértékelés. Míg az érzelmi kimerülést a másokkal való folyamatos munka magas követelményei okozzák, addig a csökkent teljesítményérzet a munkához való negatív hozzáállást, a leértékelés pedig személytelen, közönyös reakciókat takar.

A sportolói kiégés kialakulásának folyamatával kapcsolatban is többféle modell és elméleti megközelítés jött létre. Kezdetben a stresszel hozták összefüggésbe a kiégést. Smith (1986) kognitív-affektív stressz modellje, Silva (1990) negatív edzés stressz modellje és Coakley (1992) egydimenziós sportolói identitás és külsô kontroll modellje is erre épül, azonban a stressz inkább tünetként jelentkezik, kevésbé az váltja ki a kiégést. Schmidt és Stein (1991), valamint Raedeke (1997) az elkötelezôdés kontextusában vizsgálták a kiégést (Commitment and Entrapment Theory), melyhez Deci és Ryan (2000) öndetermináció-elmélete is szorosan kapcsolódik. Szerintük minél inkább élvezetalapú az elköteleződés, és magas az öndetermináció általi motiváció szintje, annál kevésbé jelenik meg a kiégés. Gustafsson integratív kiégés modellje a korábbi elméleteket igyekszik integrálni, figyelembe véve a fizikális (túledzés, kimerültség, monotonitás, teljesítménycsökkenés, inadekvát regeneráció), a pszichés (motiválatlanság, fásultság, eredménytelenség okozta frusztráció), valamint a szociális (az eredményorientált hozzáállás okozta teljesítménykényszer, civil élet kihívásai) faktorokat egyaránt, feltárva ezzel a kiégés okait, és segítve a megelőzését (Gustafsson, Kenttä és Hassmén, 2011; Gustafsson, Madigan és Lundkvist, 2018).

\section{A sportolói kiégés mérési lehetôségei}

A sportolói kiégés mérési lehetôsége nehézségekbe ütközhet, mivel kevés a validált mérôeszköz, valamint nehéz elkülöníteni egymástól a sine morbo és az érintett populációt (Maslach, Jackson, Leiter, Schaufeli és Schwab, 1986), továbbá nehezen megjósolható, kik a veszélyeztetettek (Gustafsson, Lundkvist, Podlog és Lundqvist 2016). A legelterjedtebb mérôeszköz, mely segítségével a kutatók igyekeztek bejósolni a sportolók kiégésének mértékét, a Raedeke és Smith által fejlesztett Sportolói Kiégés Kérdôív (Athlete Burnout Questionnaire, ABQ; Raedeke és Smith, 2001), melynek 
alapját a Maslach Kiégés Leltár (Maslach Burnout Inventory, MBI; Maslach és mtsai, 1986) képezi. Az ABQ kérdôív három alapvetố területet vizsgál: a fizikai és lelki kimerültséget, a csökkent teljesítôképesség érzését és a sport szubjektív értékének csökkenését (Gustafsson, Madigan és Lundkvist, 2018). A tizenöt itembôl álló mérôeszköz három alskálájának belsố konzisztenciája megfelelônek bizonyult (Érzelmi és fizikai kimerültség Cronbach $\alpha=0,88$; Teljesítménycsökkenés érzete Cronbach $\alpha=0,84$; Leértékelés Cronbach $\alpha=0,87)$. A kérdôív egyfaktoros modellje gyenge illeszkedési mutatói miatt $[\chi 2(90)=683,2, \mathrm{p}<0,01, \mathrm{GFI}=0,64, \mathrm{NNFI}=0,64, \mathrm{CFI}=0,69$, RMSEA $=0,165]$ a szerzôk a háromfaktoros modell mellett maradtak, amely megfeleló illeszkedési mutatókkal bírt $[\chi 2(87)=188,9, \mathrm{p}<0,01$, GFI $=0,90, \mathrm{NNFI}=0,94$, CFI = 0,95, RMSEA $=0,069]$. Bár a három alskála között ( $r=0,48$ és 0,62 között) pozitív irányú közepes kapcsolatot mutattak ki, fontos megemlíteni, hogy a Teljesítménycsökkenés érzete gyengébb/alacsonyabb korreláció kapcsolatot mutat a másik két alskálával és más pszichológiai változóval, mint az Érzelmi és fizikai kimerültség és a Leértékelés egymással és más pszichológiai változóval, amit gyakran kritikaként is megfogalmaznak a kérdőívvel kapcsolatban (Raedeke és Smith, 2001; Lundkvist és mtsai, 2018; Gerber és mtsai, 2018).

A kiégés alskálái pozitív irányú közepes kapcsolatot mutattak a sportolók által észlelt stressz mértékével ( $\mathrm{r}=0,43$ és 0,63 között) és az amotivációval ( $\mathrm{r}=0,46$ és 0,68 között). A szerzók negatív irányú kapcsolatot találtak az alskálák és a megküzdés ( $\mathrm{r}=-0,20$ és $-0,29$ között), a társas támasz ( $\mathrm{r}=-0,24$ és -,031 között), az örömérzet (enjoyment, $\mathrm{r}=-0,36$ és $-0,61$ között), valamint az intrinzik motiváció $(\mathrm{r}=-0,18$ és $-0,45$ között) között (Raedeke és Smith, 2001). A motiváció és kiégés kapcsolatát Lonsdale, Hodge és Rose (2009) vizsgálata is megerôsítette, azaz nemcsak az intrinzik, hanem az extrinzik motiváció autonóm formái negatív kapcsolatot mutattak a kiégéssel. A kutatás eredményei szerint a sportolói autonómia és az észlelt kompetencia a kiégés szignifikáns elôrejelzójének bizonyult.

A kérdőívet nemzetközi viszonylatban széles körben használják. A japán (Kamimura, Kawata, Raedeke és Hirosawa, 2020), a mexikói (Martínez-Alvarado és mtsai; 2019), a német (Gerber és mtsai, 2018), a francia (Isoard-Gautheur, Oger, Guillet és Martin-Krumm, 2010), a brazil (Guedes és Souza, 2016) adaptációk során a CFA megerôsítette az eredeti 15 itembôl álló kérdôív háromfaktoros modelljét, az alskálák megbízhatósága, idôbeli stabilitása $(r>0,70)$ is megfelelônek bizonyult. Egyedül a spanyol adaptáció során változott a kérdőív szerkezete (Arce, De Francisco, Andrade, Seoane és Raedeke, 2012), két itemet (a kérdôív 4. és 6. kérdését) új kérdésekre cseréltek, mivel az eredeti kérdôív illeszkedési mutatói nem bizonyultak megfelelônek. A két megváltoztatott állítással a megerôsítô faktoranalízis megfelelô illeszkedési mutatókat adott, a faktorok közötti korreláció mértéke gyenge volt $(r=0,28$ és 0,29 között), a teszt-reteszt reliabilitás megfelelônek bizonyult ( $\mathrm{r}=0,70$ és 0,81 között), akárcsak az alskálák belsố konzisztenciája (Cronbach $\alpha=0,71-0,81$ között).

A konstruktum validitás-ellenôrzése során a kiégés alskálái kapcsolatot mutattak a japán mintánál a depresszív állapottal (Kamimura és mtsai, 2020), a mexikói mintánál a sportolói elkötelezôdéssel (Martínez-Alvarado és mtsai; 2019), német sportolói közegben negatív irányú kapcsolatot az élettel való elégedettséggel és pozitív irányú kapcsolatot 
az észlelt stressz mértékével (Gerber és mtsai, 2018), a francia mintánál az öndeterminált motivációval és az önbizalommal negatív, míg az intrinzik jellegú motivációval és a kognitív állapotszorongással pozitív kapcsolat mutatkozott (Isoard-Gautheur és mtsai, 2010).

A kérdőívhez kapcsolódó késôbbi kutatás szerint az edzô vezetési stílusa és interakciós képességei hasonlóképp befolyásoló tényezók a kiégés tekintetében. Az autokrata és averzív stílusú edzôk emelik a kiégés kockázatát, míg az autonómiát támogató viselkedés és a demokratikus vezetôi stílus csökkentik azt (Altahayneh, 2003; Barcza-Renner, Eklund, Morin és Habeeb, 2016). A kiégés kialakulásának valószínúségét befolyásolják továbbá az egyéni, intraperszonális tényezôk, mint például a maladaptív perfekcionizmus (Jowett, Hill, Hall és Curran, 2016; Pacewicz, Gotwals és Blanton, 2018; Barcza-Renner és mtsai, 2016), a pesszimizmus (Gustafsson és Skoog, 2012), valamint a stressz és a szorongás (De Francisco, Arce, Pilar Vílchez és Vales, 2016; Gerber és mtsai, 2018; Granz, Schnell, Mayer és Thiel, 2019; Vealey, Armstrong, Comar és Greenleaf, 1998). Az alacsony vagy külsô motiváció (Gustafsson, DeFreese és Madigan, 2017; Russel és Molina, 2018; Martínez-Alvarado, Guillén és Feltz; 2016), az alvászavarok (Granz és mtsai, 2019), a negatív önértékelés (Gerber és mtsai 2018), a gyakori hangulatingadozás (Tenenbaum, Jones, Kitsantas, Sacks és Berwick, 2003), az érzelmi izoláció és interperszonális kapcsolatok nehézségei (Cresswell és Eklund, 2006) is a sportolói kiégés következményei közé sorolhatók.

A nemzetközi szakirodalom alapján célunk az $\mathrm{ABQ}$ hazai változatának elkészítése, hogy elsôként létrehozzunk és alkalmazhatóvá tegyünk a gyakorlat számára is egy olyan kérdőívet, mely megbízhatóan képes mérni a sportolók kiégését, és segíteni tudja a lemorzsolódás elkerülését és csökkentését.

\section{MÓDSZER}

\section{Eljárás és adatfelvétel}

A skálák fordítása során Banville, Desrosiers és Genet-Volet (2000) ajánlását követtük. A Sportolói Kiégés Kérdôív fordítását angolról magyarra két szakfordító végezte, majd a két változat összevetésébôl és megvitatásából készült tételsort egy angol szakfordító fordította vissza az eredeti nyelvre. A visszafordítás ellenôrzését és jóváhagyását egy sportszakpszichológus szakfordító végezte. A kérdőívek magyar nyelvre fordítását a kérdôív jogtulajdonosa jogilag engedélyezte akadémiai kutatók részére.

Az adatfelvétel 2018. szeptember és 2019. május között zajlott le, egyetemi (Testnevelési Egyetem, Károli Gáspár Református Egyetem, Szegedi Tudományegyetem) hallgatók közremúködésével, különbözô egyetemi kurzusok keretében. Az adatfelvétel kényelmi mintavételi eljárással történt: a hallgatók a szemináriumi munka részeként, általuk közvetlen vagy közvetett módon elért sportegyesületek, szakképzett edzók segítségével jutottak el a vizsgálati személyekhez. A résztvevók egy kisebb csoportját a spanyol adaptációs kutatással (Arce és mtsai, 2012) összhangban két hét elteltével ismételt tesztfelvételre kértük fel, a teszt-reteszt reliabilitás ellenôrzésének érdekében. 
A felkeresett szövetségeket, egyesületeket és a részt vevô fiatalkorú sportolók szüleit, valamint a sportolókat egyaránt tájékoztattuk a vizsgálat céljáról és a méróeszközök tartalmáról. Utánpótlás korosztályok esetében szülôi beleegyezô nyilatkozatot kértünk, és biztosítottuk a sportolók számára az anonimitást. A kérdôív kitöltése kb. 25-30 percet vett igénybe. A kutatást a Testnevelési Egyetem Kutatásetikai Bizottsága jóváhagyta, az engedély száma: TE-KEB/No9/2019.

\section{Minta}

Adatfelvételünket összesen 1317 fiatal sportolóval végeztük el, akiknek átlagéletkora 20,45 év ( $\min =13$ év; $\max =35$ év; SD = 4,40 év) volt. A nemek megoszlása közel egyenlô volt, 649 férfi és 668 nô vett részt a kutatásunkban. A megkérdezettek 27 sportág képviselôi voltak, és 50,7\%-uk csapatsportágat, 49,3\%-uk pedig egyéni sportágat képviselt. A minta résztvevôi átlagosan 10,64 éve sportoltak $(\mathrm{SD}=5,29$ év; min = 0 év; max = 30 év), és hetente átlagosan 9,56 órát ( $\mathrm{SD}=6,26$ óra) töltöttek edzéssel. A megkérdezettek nagy része nemzetközi $(15,6 \%)$ vagy országos $(38,7 \%)$ szinten sportolt, és sokan sportoltak helyi $(19,1 \%)$ és hobbiszinten $(26,6 \%)$ is.

\section{Méröeszközök}

Az összeállított kérdôívcsomagban szerepeltek a sportolók szociodemográfiai adataira (pl. nem, életkor), valamint a sportággal és sportolással kapcsolatos háttérinformációkra (pl. sportág megnevezése, heti edzésszám, az adott sportágban eltöltött évek száma, versenyzés szintje) vonatkozó kérdések.

\section{Sportolói Kiégés Kérdōiv}

A sportolói kiégést a Sportolói Kiégés Kérdőívvel vizsgáltuk (Athletic Burnout Questionnaire -ABQ; Raedeke és Smith, 2001). A kérdőív 15 tételt tartalmaz, és a válaszadóknak egy 5 fokú Likert-skálán kellett a válaszokat megadniuk ( 1 = teljesen egyetértek; 5 = egyáltalán nem értek egyet). A kérdőív három alskálája: Teljesítménycsökkenés érzete (pl. „Úgy érzem, érdemleges teljesítményt érek el a sportban.”), Érzelmi és fizikai kimerültség (pl. „Annyira fáradtnak érzem magam az edzéstôl, hogy nehezen találok energiát más dolgokra.”) és Leértékelés (pl. „Kevésbé aggódom, hogy sikeres legyek a sportban, mint régebben.”). A magas pontértékek a kiégés magasabb mértékét jelzik.

\section{Sportkörnyezet Kérdöiv (SCQ-H)}

A kérdôív (Sport Climate Questionnaire - Deci, 2001; Kovács, Gyömbér, F. Földi és Lénárt, megjelenés alatt) célja, hogy felmérje, milyen mértékú autonómiatámogató viselkedést észlel a sportoló az edzője felool (pl. „Úgy érzem, az edzóm elfogad engem.”). A kérdôív 12 itemból áll, nem tartalmaz fordított tételt (Cronbach $\alpha=0,94)$. 
A kérdésekre a kitöltôk hétfokú Likert-skálán adják meg a választ ( 1 = Egyáltalán nem értek egyet; 4 = Semleges; 7 = Teljesen egyetértek), a magasabb pontértékek az autonómiatámogatás magasabb szintjét jelzik.

\section{Sportmotivációs Kérdōiv (SMS-II)}

A kérdôív (Pelletier, Rocchi, Vallerand, Deci és Ryan, 2013, Smohai és mtsai, 2019) az öndeterminációs elmélet keretein belül méri a sportolói motiváció mértékét és típusát. A 18 itembôl álló kérdőívben a válaszadók egy hétfokú Likert-skálán jelölhetik a válaszukat ( 1 = egyáltalán nem jellemzô; 7 = nagyon jellemzô). A skála hat faktora: Intrinzik motiváció, Integrált motiváció, Identifikált motiváció, Introjektált motiváció, Külsố szabályozás és Amotiváció (Cronbach $\alpha=0,62-0,80$ ). A skála hat faktorának pontszámát a tételekre adott válaszok összegzése adja, a magasabb érték az adott motivációs típus magasabb szintjét jelenti.

\section{Majdnem Tökéletes Skála - rövid változat (SAPS)}

A nyolc itemból álló kérdőív (Short Almost Perfect Scale - Reinhardt, Tóth és Rice, 2019) a perfekcionizmus mértékét vizsgálja. A kitöltés során a kitöltők egy hétfokú Likert-skálán jelölhetik a válaszukat ( 1 = egyáltalán nem értek egyet; 7 = Teljes mértékben egyetértek). A skála két faktora a Standardok (Cronbach $\alpha=0,86$ ), a személy magával szemben támasztott elvárásai (pl. „Magasak az elvárásaim önmagammal szemben.”) és a Diszkrepancia (Cronbach $\alpha=0,77$ ), a teljesítményértékeléshez kapcsolódó önkritikus attitûdök (pl. „Nekem a tôlem telhetô legjobb sem elég soha.”).

\section{Statisztikai módszer}

A leíró statisztikai mutatók (átlag és szórás) mellett az AMOS 20.0 szoftverrel ellenôrzô faktoranalízissel megvizsgáltuk a Sportolói Kiégés Kérdôív faktorszerkezetét, melyhez Raedeke és Smith (2001) háromfaktoros struktúráját használtuk fel. A maximum likelihood becslési módszerrel végzett vizsgálatunk eredményeit több erre a célra létrehozott illeszkedési mutatóval elemeztük. Ezek a következók voltak: khi négyzet $(\chi 2)$, a khi négyzet, valamint a szabadságfok hányadosából adódó érték (CMIN/d.f); root mean square error of approximation (RMSEA); a Tucker-Lewis-index (TLI); comparative fit index (CFI); standardized root mean square residual (SRMR). Az illeszkedési mutatók elfogadható értékeivel kapcsolatban követtük a szakirodalom ajánlásait. Ezek szerint a khi négyzet $(\chi 2)$ akkor fogadható el, ha nem szignifikáns értéket mutat, azonban az köztudott, hogy érzékeny az elemszámra, így a kutatók azt javasolják, hogy a relatív khi négyzet értékét vizsgáljuk. Ez az érték a khi négyzet és a szabadságfok által létrejött hányados (CMIN/d.f), melynek értéke elfogadható, ha 5 alatt van (Byrne, 2010; Hu és Bentler, 1999), de 3 alatt az értéke kiváló (Garson, 2015). Az RMSEA értéke független a mintától, és 0,08 alatti értéknél elfogadhatónak mondhatjuk (Byrne, 2010; Hooper, Coughlan és Mullen, 2008). A Tucker-Lewis-index szintén független a minta nagyságától. Az értéke mindig 0 és 1 közé esik, és akkor mutat jó illeszkedést, 
ha értéke 0,90 fölé esik (Hu és Bentler, 1999). Az összehasonlító illeszkedési mutató (CFI) az adatok és a hipotetikus modell közötti különbséget vizsgálja. Megmutatja, hogy a modellünk, a null modell és a tökéletesen illeszkedố modell között milyen illeszkedés található. Az értéke szintén 0 és 1 közé esik, és csakúgy, mint az elózôekben, 0,90 fölött mutat jó illeszkedést, de minél magasabb az értéke, annál jobb a modell illeszkedése. Az SRMR értéke a minta és a modell kovarianciamátrixa közötti eltérést mutatja. Ha az érték kisebb, mint 0,08, akkor elfogadható illeszkedésrôl beszélünk (Bryant és Satorra, 2012).

Megvizsgáltuk a minta megbízhatósági mutatóit is. Ehhez az ún. átlagos megmagyarázott variancia értékét (Average Variance Explained; AVE), az indikátorhoz tartozó fogalmi megbízhatósági mutatót (Composite Reliablitity; CR), valamint a széles körben ismert Cronbach alfát használtuk. Az AVE értéke 0,50-ös értéktôl válik elfogadhatóvá, míg a Cronbach alfa és CR értéke 0,70-tôl fogadható el (Hair, Black, Babin és Anderson, 2009).

\section{EREDMÉNYEK}

Az elsố táblázat tartalmazza a vizsgált változók leíró statisztikáját (átlag, szórás, Cronbach alfa, ferdeség, csúcsosság). A teljesítmény csökkenése faktor változóinak átlagértékei 2,09 és 2,70 között változnak, a fizikai és szellemi kimerültség változói 1,82 és 2,57 között, míg a leértékelései 1,74 és 2,35 között mozognak a mintánkban. Mind a három faktor megbízhatósági mutatói jónak mondhatók, hiszen minden esetben jóval a 0,7-es érték fölötti eredményt kaptunk. A vizsgált változók legtöbbje minimálisan, de kívül esik a normális eloszlás kritériumain (lásd 1. táblázat).

1. táblázat. A bevont változók leíró statisztikája

\begin{tabular}{lcccccc}
\hline Faktor & Cr. alfa & Item & Átlag & Szórás & Ferdeség & Csúcsosság \\
\hline Teljesítmény csökkenése & 0,76 & 1 & 2,39 & 1,02 & 0,62 & 0,00 \\
& & 7 & 2,55 & 1,23 & 0,39 & $-0,83$ \\
& & 5 & 2,25 & 1,11 & 0,64 & $-0,39$ \\
& & 13 & 2,09 & 1,19 & 0,85 & $-0,30$ \\
& & 14 & 2,70 & 1,19 & 0,45 & $-0,67$ \\
\hline Fizikai és szellemi kime- & 0,86 & 2 & 2,57 & 1,19 & 0,32 & $-0,85$ \\
rültség & & 4 & 2,09 & 1,06 & 0,78 & $-0,10$ \\
& & 8 & 1,82 & 1,07 & 1,32 & 1,02 \\
& & 10 & 2,11 & 1,12 & 0,87 & $-0,01$ \\
& & 12 & 1,97 & 1,11 & 1,06 & 0,36 \\
\hline Leértékelés & 0,78 & 3 & 1,88 & 1,10 & 1,13 & 0,38 \\
& & 6 & 2,35 & 1,35 & 0,57 & $-1,00$ \\
& & 9 & 1,74 & 1,10 & 1,44 & 1,13 \\
& & 11 & 2,29 & 1,37 & 0,62 & $-0,97$ \\
& & 15 & 1,77 & 1,07 & 1,35 & 0,95 \\
\hline
\end{tabular}




\section{Megerôsitô faktoranalizis}

Vizsgálatunk következô részében Raedeke és Smith (2001) eredményei alapján a 15 tételbôl egy három látens változót tartalmazó modellt alakítottunk ki (1. ábra). A maximum likelihood becslési módszerrel elvégzett elemzésünk a következô eredményeket hozta: A teljesítmény csökkenése változó faktortöltései 0,48 és 0,80 között mozogtak, míg a leértékelésnél 0,66 és 0,81 között alakult ez a szám. A fizikai és szellemi kimerültség faktortöltései voltak a legerósebbek, melyek 0,71 és 0,88 között mozogtak.

A teljes mintára nézve nem minden illeszkedési mutató érte el a kívánt értékeket $\left(\mathrm{x}^{2} / \mathrm{df}=6,55 ;\right.$ TLI $=0,92 ; \mathrm{CFI}=0,95 ;$ RMSEA $=0,06 ;$ SRMR $\left.=0,05\right)$, ugyanakkor almintánként (nem, kor, sportág) elemezve mintánkat már jobb értékeket kapunk (2. táblázat). Nemenként vizsgálva minimális különbség van férfiak és a nốk között. A korosztályokat vizsgálva valamennyi esetben jó illeszkedési mutatókkal találkozhatunk, ugyanakkor a serdülő korosztályoknál találhatók a legjobb illeszkedési mutatók. Megvizsgáltuk az illeszkedést különbözó sportágak képviselôi között is. Egyéni és csapatsportolókra osztva a mintát arra a megállapításra jutottunk, hogy az egyéni versenyzôknél az illeszkedés kiváló, míg a csapatsportolók esetében csupán elfogadhatók az értékek. Valamennyi alskálán legalább elfogadható értékeket kaptunk, ezért úgy látjuk, hogy a 15 tételes és 3 faktoros szerkezet kellóképpen lefedi a kiégés okait a magyar sportoló fiatalok között.

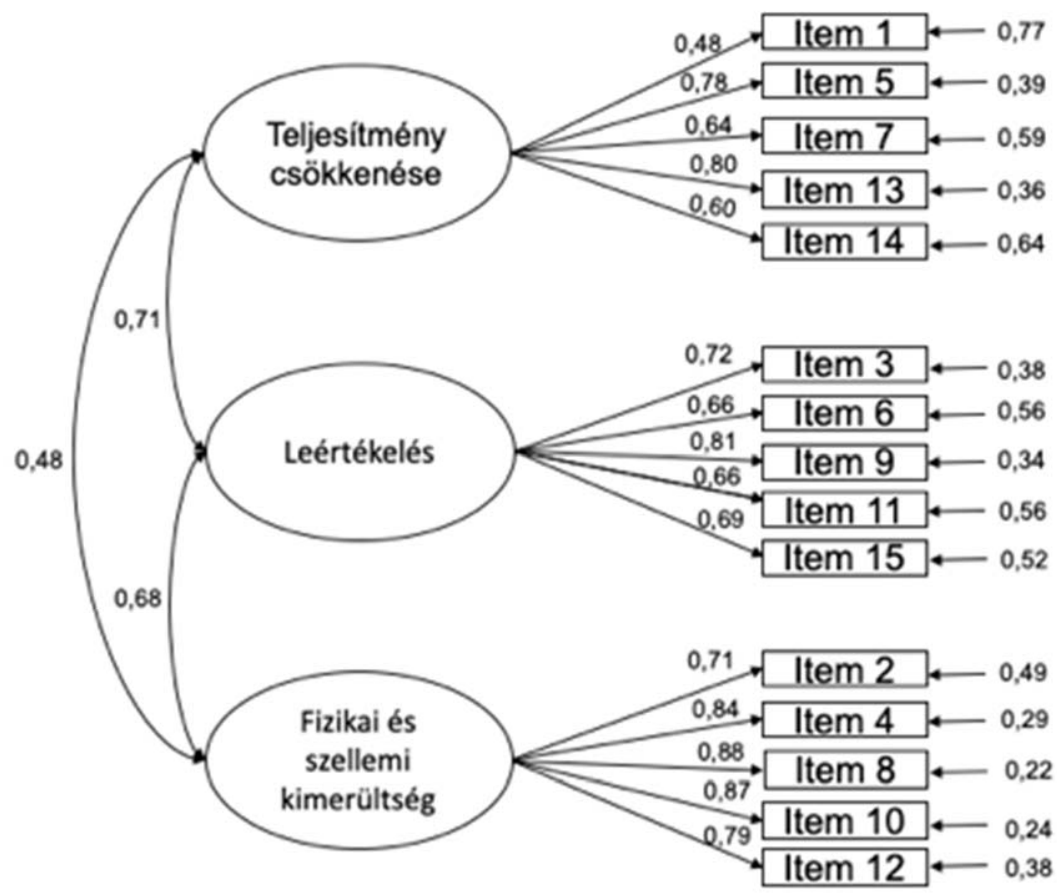

1. ábra. ABQ-H faktor szerkezete, faktor töltése és korrelációja 
2. táblázat. Az ABQ-H illeszkedési mutatói a teljes mintán, valamint almintákra lebontva

\begin{tabular}{lrccccccc}
\hline Modell & \multicolumn{1}{c}{$\mathrm{n}$} & $\mathrm{x}^{2}$ & $\mathrm{DF}$ & $\mathrm{x}^{2} / \mathrm{df}$ & $\mathrm{TLI}$ & $\mathrm{CFI}$ & RMSEA & SRMR \\
\hline Teljes minta & 1317 & 458,52 & 70 & 6,55 & 0,92 & 0,95 & 0,06 & 0,05 \\
Fiúk & 649 & 293,71 & 70 & 4,19 & 0,90 & 0,94 & 0,07 & 0,06 \\
Lányok & 668 & 321,70 & 70 & 4,50 & 0,92 & 0,95 & 0,07 & 0,06 \\
$14-15$ & 97 & 112,76 & 70 & 1,61 & 0,92 & 0,95 & 0,08 & 0,08 \\
$16-18$ & 424 & 217,82 & 70 & 3,11 & 0,93 & 0,95 & 0,07 & 0,05 \\
$19-21$ & 407 & 261,62 & 70 & 3,73 & 0,93 & 0,91 & 0,08 & 0,06 \\
$22-35$ & 389 & 210,26 & 70 & 3,00 & 0,89 & 0,92 & 0,07 & 0,06 \\
Egyéni & 460 & 196,70 & 70 & 2,81 & 0,94 & 0,96 & 0,06 & 0,05 \\
Csapat & 439 & 258,65 & 70 & 3,69 & 0,91 & 0,94 & 0,07 & 0,07 \\
\hline
\end{tabular}

\section{Megbízhatósági mutatók}

Elemzésünk utolsó részében a megbízhatósági mutatókat vizsgáltuk meg. Ehhez három mutatót, az ún. átlagos megmagyarázott variancia értékét, az indikátorhoz tartozó fogalmi megbízhatósági mutatót, valamint a Cronbach alfát használtuk. A megbízhatósági mutatóinkat a 3. táblázatban ismertetjük a teljes mintára vonatkozóan, valamint

3. táblázat. Az ABQ-H skála megbízhatósági mutatói a teljes mintán, valamint almintákra lebontva

\begin{tabular}{|c|c|c|c|c|}
\hline Minta & Faktorok & Cronbach alpha & AVE & CR \\
\hline Teljes minta & $\begin{array}{l}\text { Teljesítmény csökkenése } \\
\text { Fizikai és szellemi kimerültség } \\
\text { Leértékelés }\end{array}$ & $\begin{array}{l}0,76 \\
0,86 \\
0,78\end{array}$ & $\begin{array}{l}0,45 \\
0,67 \\
0,50\end{array}$ & $\begin{array}{l}0,79 \\
0,91 \\
0,83\end{array}$ \\
\hline Fiú & $\begin{array}{l}\text { Teljesítmény csökkenése } \\
\text { Fizikai és szellemi kimerültség } \\
\text { Leértékelés }\end{array}$ & $\begin{array}{l}0,72 \\
0,85 \\
0,71\end{array}$ & $\begin{array}{l}0,48 \\
0,59 \\
0,51\end{array}$ & $\begin{array}{l}0,74 \\
0,87 \\
0,79\end{array}$ \\
\hline Leány & $\begin{array}{l}\text { Teljesítmény csökkenése } \\
\text { Fizikai és szellemi kimerültség } \\
\text { Leértékelés }\end{array}$ & $\begin{array}{l}0,78 \\
0,87 \\
0,80\end{array}$ & $\begin{array}{l}0,43 \\
0,63 \\
0,56\end{array}$ & $\begin{array}{l}0,77 \\
0,89 \\
0,81\end{array}$ \\
\hline $14-15$ & $\begin{array}{l}\text { Teljesítmény csökkenése } \\
\text { Fizikai és szellemi kimerültség } \\
\text { Leértékelés }\end{array}$ & $\begin{array}{l}0,81 \\
0,89 \\
0,87\end{array}$ & $\begin{array}{l}0,52 \\
0,69 \\
0,65\end{array}$ & $\begin{array}{l}0,78 \\
0,91 \\
0,90\end{array}$ \\
\hline $16-18$ & $\begin{array}{l}\text { Teljesítmény csökkenése } \\
\text { Fizikai és szellemi kimerültség } \\
\text { Leértékelés }\end{array}$ & $\begin{array}{l}0,78 \\
0,87 \\
0,84\end{array}$ & $\begin{array}{l}0,56 \\
0,63 \\
0,54\end{array}$ & $\begin{array}{l}0,79 \\
0,87 \\
0,82\end{array}$ \\
\hline $19-21$ & $\begin{array}{l}\text { Teljesítmény csökkenése } \\
\text { Fizikai és szellemi kimerültség } \\
\text { Leértékelés }\end{array}$ & $\begin{array}{l}0,76 \\
0,82 \\
0,73\end{array}$ & $\begin{array}{l}0,45 \\
0,58 \\
0,43\end{array}$ & $\begin{array}{l}0,77 \\
0,87 \\
0,72\end{array}$ \\
\hline $22-35$ & $\begin{array}{l}\text { Teljesítmény csökkenése } \\
\text { Fizikai és szellemi kimerültség } \\
\text { Leértékelés }\end{array}$ & $\begin{array}{l}0,72 \\
0,84 \\
0,71\end{array}$ & $\begin{array}{l}0,45 \\
0,65 \\
0,46\end{array}$ & $\begin{array}{l}0,71 \\
0,90 \\
0,72\end{array}$ \\
\hline Egyéni & $\begin{array}{l}\text { Teljesítmény csökkenése } \\
\text { Fizikai és szellemi kimerültség } \\
\text { Leértékelés }\end{array}$ & $\begin{array}{l}0,78 \\
0,89 \\
0,79\end{array}$ & $\begin{array}{l}0,50 \\
0,65 \\
0,48\end{array}$ & $\begin{array}{l}0,73 \\
0,90 \\
0,72\end{array}$ \\
\hline Csapat & $\begin{array}{l}\text { Teljesítmény csökkenése } \\
\text { Fizikai és szellemi kimerültség } \\
\text { Leértékelés }\end{array}$ & $\begin{array}{l}0,80 \\
0,87 \\
0,77\end{array}$ & $\begin{array}{l}0,52 \\
0,65 \\
0,46\end{array}$ & $\begin{array}{l}0,76 \\
0,90 \\
0,74\end{array}$ \\
\hline
\end{tabular}


almintákra lebontva. A kapott megbízhatósági értékek a legtöbb helyen megfelelônek mondhatók, de az határozottan látszik, hogy a serdülő korosztályban (14-18 éves korosztály) a legmagasabbak a megbízhatósági értékek, ami összhangban van az illeszkedési mutatóknál kapott eredményeinkkel is.

\section{Teszt-reteszt reliabilitás}

A kérdôíveket kéthetes eltéréssel töltötte ki a résztvevók egy kisebb, újonnan megkeresett csoportja. A teszt-reteszt elemzés $(\mathrm{n}=123$, ffi $=74$, nó $=49 ; \mathrm{M}=21,02$ év; $\mathrm{SD}=.4,73$ év) alapján szignifikáns, pozitív erôs kapcsolat található a két kitöltés között mind a három alskála tekintetében: Érzelmi és fizikai kimerültség - r $(121)=$ $0,92, \mathrm{p}<0,001$; Leértékelés $-\mathrm{r}(123)=0,90, \mathrm{p}<0,001$; Teljesítménycsökkenés érzete $-\mathrm{r}(123)=0,60, \mathrm{p}<0,001$.

\section{Érvényesség - Konvergens validitás}

Az ABQ skálái és az észlelt edzôi autonómia, a sportmotiváció és a perfekcionizmus közötti kapcsolatot Pearson-féle product-moment korrelációs vizsgálattal elemeztük.

A Teljesítménycsökkenés érzete faktor szignifikáns, pozitív irányú, gyenge erejú kapcsolatot mutatott az Amotivációval, szignifikáns, negatív irányú, gyenge kapcsolatot mutatott az edzői autonómiatámogatás mértékével, az Intrinzik, Integrált és Identifikált szabályozással, valamint a perfekcionizmus skála Standardok alskálájával.

Az Érzelmi és fizikai kimerültség faktor szignifikáns pozitív gyenge kapcsolatot mutatott az Amotivációval és a Külsô szabályozással, valamint szignifikáns negatív gyenge kapcsolatot mutatott az edzôi autonómiatámogatás mértékével és Standardok alskálájával. Szignifikáns, de értékében elhanyagolható kapcsolat található az Intrinzik, Integrált és az Identifikált szabályozással.

A Leértékelés faktor szignifikáns pozitív közepes erôsségú kapcsolatot mutatott az Amotivációval. Szignifikáns negatív gyenge kapcsolatot találtunk az adott faktor, valamint az edzôi autonómiatámogatás mértéke között, továbbá az Intrinzik és Integrált szabályozás alskálák között. Szignifikáns, de értékében elhanyagolható kapcsolat található az alskála és az Introjektált és az Identifikált szabályozás között.

\section{MEGBESZÉLÉS}

A sportolói kiégés vizsgálata nemzetközi viszonylatban a széleskörúen vizsgált területek közé tartozik, amelyet leggyakrabban a Sportolói Kiégés Kérdôívvel (ABQ) szoktak felmérni. A kutatásunk célja, hogy ezt az eszközt adaptáljuk magyar nyelvre, így elérhetôvé tegyük a hazai szakemberek számára is. Az eredmények alapján a kérdôív belsố megbízhatósága megfeleloonek bizonyult, a megerôsítô faktoranalízis igazolta a vizsgált itemek hármas faktorszerkezetét. Eredményünk elfogadható illeszkedést és jó megbízhatóságot mutat, ám a faktortöltések tekintetében jelentôsen elmaradt az eredeti tanulmányétól (Raedeke és Smith, 2001). Ugyanakkor hasonló problémával ta- 
4. táblázat. A kérdőív magyarra fordított változata konstruktumvaliditásának ellenôrzése

\begin{tabular}{llccc}
\hline & & $\begin{array}{c}\text { Érzelmi és fizi- } \\
\text { kai kimerültség }\end{array}$ & $\begin{array}{c}\text { Leértékelés } \\
\text { SCQ }\end{array}$ & $\begin{array}{c}\text { Teljesítménycsökkenés } \\
\text { érzete }\end{array}$ \\
\hline \multirow{2}{*}{ támogatás } & Amotiváció & $-0,31^{* *}$ & $-0,31^{* *}$ & $-0,31^{* *}$ \\
& Külsố szabályozás & $0,39^{* *}$ & $0,52^{* *}$ & $0,37^{* *}$ \\
\multirow{2}{*}{ SMS-II autonómia- } & $0,24^{* *}$ & $0,15^{* *}$ & $0,15^{* *}$ \\
& Introjektált szabályozás & $-0,02$ & $-0,08^{* *}$ & $-0,04$ \\
& Identifikált szabályozás & $-0,17^{* *}$ & $-0,19^{* *}$ & $-0,32^{* *}$ \\
& Integrált szabályozás & $-0,18^{* *}$ & $-0,31^{* *}$ & $-0,36^{* *}$ \\
& Intrinzik szabályozás & $-0,14^{* *}$ & $-0,32^{* *}$ & $-0,30^{* *}$ \\
\hline \multirow{2}{*}{ SAPS } & Standardok & 0,07 & $-0,20^{* *}$ & $-0,21^{* *}$ \\
& Diszkrepancia & $0,20^{* *}$ & $-0,05$ & $0,18^{* *}$ \\
\hline
\end{tabular}

$* * p<0,01$

lálkozhatunk a szakirodalomban is (Martínez-Alvarado és mtsai, 2019). A teljes minta ugyan nem illeszkedett tökéletesen a hármas szerkezethez, ám az almintákon már kifejezetten jó értékeket kaptunk. Nemenként vizsgálva a faktorszerkezetet közel azonos eredményeket kaptunk a két nem között. Korosztályos almintáknál azonban már más a helyzet. Míg a 14-16 és 17-18 évesek között az illeszkedési és megbízhatósági mutatók is kiválónak bizonyultak, addig az idôsebb korosztályoknál már ezek az értékek alacsonyabbak. Ez az eredmény egyáltalán nem meglepó, hiszen a külföldi adaptációs vizsgálatok (pl. Isoard-Gautheur és mtsai, 2010), valamint Raedeke és Smith (2001) eredeti tanulmánya is inkább a serdülô korosztályt célozta meg. Természetesen a kiégésnek nem csak a serdülők vannak kitéve, de a vizsgált kérdôív leginkább az ô felmérésükre bizonyult alkalmasnak. Ezek mellett sportágtípusonként is megvizsgáltuk a mintát, ahol azt tapasztaltuk, hogy az illeszkedési mutatók közel azonos nagyságúak az egyéni és a csapatsportot ûzôk körében.

A kérdóívet tovább elemezve, a szakirodalomban leírtaknak megfelelóen (Altahayneh, 2003, Gustafsson és mtsai, 2011; Barcza-Renner és mtsai, 2016) kapcsolatot találtunk az észlelt edzői autonómiatámogatás mértéke és a Sportolói Kiégés Kérdôív alskálái között. A sportolói kiégés kiváltó tényezôi közé sorolható az edzô-sportoló közötti nem megfelelô kapcsolat, azonban az edzô preventív légkört teremthet azáltal, hogy biztosítja a döntés lehetôségét a sportolója számára, és támogatja annak autonómiáját. Raedeke és Smith (2001) is felhívta a figyelmet a társas támasz szerepére a kiégés megelőzésével kapcsolatban, amelyben az észlelt edzói viselkedésnek is jelentôs szerepe van. Hozzájárulhat a kiégéshez az autoriter edzôi stílus, ahol az edzôi instrukciók és irányítás dominánsan jelen van, és ahol a sportoló igényei, véleménye háttérbe szorul; míg a demokratikus edzôi stílus, ahol biztosítják a sportolók számára a döntéshozatal lehetôségét meghatározott keretek között, csökkentheti a teljesítménycsökkenés érzetének kialakulását (Altahayneh, 2003).

Az Amotiváció mindhárom alskálával, míg a Külsố szabályozás az Érzelmi és fizikai kimerültség alskálával mutatott kapcsolatot, azaz a kiégés mértékének növekedése együtt jár az öndeterminált motiváció csökkenésével. Mindezt megerôsíti - a nem- 
zetközi tapasztalatoknak megfelelően -, hogy az öndetermináció felé mutató skálák (Identifikált, Integrált és Intrinzik szabályozás) negatív kapcsolatba hozhatók a Sportolói Kiégés Kérdôív alskáláival. A témában releváns legtöbb sportpszichológiai elmélet (Raedeke, 1997; Gustafsson és mtsai, 2011) is a kiégés elójeleként tartotta számon a motivációhiányt, és számos kutatás kimutatta az összefüggéseket közöttük (Gustafsson és mtsai, 2017; Russel és Molina, 2018; Martínez-Alvarado és mtsai, 2016). Fontos megemlíteni, hogy bár a Teljesítménycsökkenés érzete alskálákhoz társítják a gyengébb korrelációs mutatókat, a hazai mintán ezzel szemben az Érzelmi és fizikai kimerültség alskála jellemezhetố hasonló tulajdonsággal a sportolói motiváció kapcsolatában. Késôbbi kutatások fontos feladata lehet a jelenség hátterének feltárása - a kimerültség pontosan milyen hatással bír a sportoló motiváltságára.

A perfekcionizmus kérdôív Standardok alskálája negatív összefüggést mutat a Leértékelés és Teljesítménycsökkenés érzete alskálákkal, míg a Diszkrepancia pozitív kapcsolatba hozható az Érzelmi és fizikai leértékelés alskálával, azaz a maladaptív perfekcionizmus (Jowett és mtsai, 2016, Pacewicz és mtsai, 2018; Gustafsson és mtsai, 2011; Barcza-Renner és mtsai, 2016) a kiégés kiváltó tényezői közé sorolható.

Az önkitöltôs kérdôívek sajátosságai miatt fontos megemlíteni a kutatás limitációjaként a szociális megfelelési torzítás hatását, így a jövôben érdemes lehet a vizsgálatot egy ezt mérô skálával kiegészíteni. Továbbá fontos megjegyezni, hogy ugyan jó illeszkedési mutatókkal rendelkeztek a modellek, az alskálák faktortöltései mégis alacsony szinten maradtak, ami további vizsgálatra sarkall bennünket. Vizsgálatunk egyik legfontosabb korlátja, hogy a kérdôív szinte csak a serdülô korosztályban használható megbízhatóan. További limitációt jelent az, hogy az ABQ kérdóívet jelen formájában elsôsorban kutatási célokra lehet jól használni. A gyakorlatban való jó használhatóságához szükség lenne egy kritériumrendszer kidolgozására, amellyel lehetôség nyílna a normálövezet és a kiégésben érintett kitöltôk megbízható elkülönítésére.

Összességében a kérdôív jól alkalmazhatónak bizonyult, és megfelelô megbízhatósággal rendelkezik mind a belsố konzisztencia, mind az idôi stabilitás kapcsán. Az új magyar változat tovább gazdagítja az alkalmazott sportpszichológia gyakorlati szegmensét, és hozzájárulhat a versenyzôk korai lemorzsolódásával és kiégésével kapcsolatos preventív és intervenciós programok kialakításához.

\section{IRODALOM}

Altahayneh, Z. (2003). The effects of coaches' behaviors and burnout on the satisfaction and burnout of athletes. Disszertáció. Letöltve 2020. 06. 26-án: http://purl.flvc.org/fsu/fd/FSU_migr_ etd-0005

Arce, C., De Francisco, C., Andrade, E., Seoane, G., \& Raedeke, T. (2012). Adaptation of the Athlete Burnout Questionnaire in a Spanish sample of athletes. The Spanish Journal of Psycho$\log y, 15(3), 1529$.

Banville, D., Desrosiers, P., \& Genet-Volet, Y. (2000). Translating Questionnaires and Inventories Using a Cross-cultural Translation Technique. Journal of Teaching in Physical Education, 19(3), 374-387. 
Barcza-Renner, K., Eklund, R. C., Morin, A. J., \& Habeeb, C. M. (2016). Controlling Coaching Behaviors and Athlete Burnout: Investigating the Mediating Roles of Perfectionism and Motivation. Journal of Sport and Exercise Psychology, 38(1), 30-44.

Bryant, F. B., \& Satorra, A. (2012). Principles and Practice of Scaled Difference Chi-Square Testing. Structural Equation Modeling: A Multidisciplinary Journal, 19(3), 372-398.

Byrne, B. M. (2010). Structural Equation Modeling with AMOS: Basic Concepts, Applications and Programming. London: Routledge.

Coakley, J. (1992). Burnout among Adolescent Athletes: A personal failure or social problem? Sociology of Sport Journal, 9(3), 271-285.

Cresswell, S., \& Eklund, R. (2006). The Nature of Player Burnout in Rugby: Key Characteristics and Attributions. Journal of Applied Sport Psychology, 18(3), 219-239.

Deci, E. L. (2001). The Sport Climate Questionnaire. Letöltve 2018. 07. 18-án: http://selfdeterminationtheory.org/pas-sport-climate/

Deci, E. L., \& Ryan, R. M. (2000). The "what" and "why" of goal pursuits: Human needs and the self-determination of behavior. Psychological Inquiry, 11(4), 227-268.

DeFrancisco, C., Arce, C., Del Pilar Vílchez, M., \& Vales, Á. (2016). Antecedents and Consequences of Burnout in Athletes: Perceived Stress and Depression. International Journal of Clinical and Health Psychology, 16(3), 239-246.

Garson, G. D. (2015). Structural equation modeling. Asheboro, NC: Statistical Associates Publishers.

Gerber, M., Gustafsson, H., Seelig, H., Kellmann, M., Ludyga, S., Colledge, F., Brand, S., Isoard-Gautheur, S., \& Bianchi, S. (2018). Usefulness of the Athlete Burnout Questionnaire $(\mathrm{ABQ})$ as a Screening Tool for the Detection of Clinically Relevant Burnout Symptoms among Young Elite Athletes. Psychology of Sport and Exercise, 39, 104-113.

Granz, H. L., Schnell, A., Mayer, J., \& Thiel, A. (2019). Risk Profiles for Athlete Burnout in Adolescent Elite Athletes: A Classification Analysis. Psychology of Sport and Exercise, 41, 130-141.

Guedes, D. P., \& Souza, R. O. D. (2016). Psychometric Properties of the Athlete Burnout Questionnaire for Young Brazilian Athletes. Journal of Physical Education, 27, 1-12.

Gustafsson, H., Kenttä, G., \& Hassmén, P. (2011). Athlete burnout: an integrated model and future research directions. International Review of Sport and Exercise Psychology, 4(1), 3-24.

Gustafsson, H., Lundkvist, E., Podlog, L., \& Lundqvist, C. (2016). Conceptual Confusion and Potential Advances in Athlete Burnout Research. Perceptual and Motor Skills, 123(3), 784-791.

Gustafsson, H., \& Skoog, T. (2012). The Mediational Role of Perceived Stress in the Relation between Optimism and Burnout in Competitive Athletes. Anxiety, Stress \& Coping, 25(2), 183-199.

Gustafsson, H., DeFreese, J. D., \& Madigan, D. J. (2017). Athlete Burnout: Review and Recommendations. Current Opinion in Psychology, 16, 109-113.

Gustafsson, H., Madigan, D. J., \& Lundkvist, E. (2018). Burnout in athletes. In Fuchs, R. \& Gerber, M. (Eds), Handbuch Stressregulation und Sport (pp. 489-504.). Berlin, Heidelberg: Springer.

Hair, J. F., Jr., Black, W. C., Babin, B. J., \& Anderson, R. E. (2009). Multivariate Data Analysis. Upper Saddle River, NJ: Prentice Hall.

Hooper, D., Coughlan, J., \& Mullen, M. R. (2008). Structural Equation Modelling: Guidelines for Determining Model Fit. Journal of Business Research Methods, 6, 53-60.

Hu, L., \& Bentler, P. M. (1999). Cut-Off Criteria for Indexes in Covariance Structure Analysis: Conventional Criteria versus New Alternatives. Structural Equation Modelling, 6, 1-55.

Hughes, P. (2014). Association between athlete burnout and athletic injury. Letöltve 2019. 05. 14-én: https://cdr.lib.unc.edu/concern/dissertations/gx41mj654 
Isoard-Gautheur, S., Oger, M., Guillet, E., \& Martin-Krumm, C. (2010). Validation of a French Version of the Athlete Burnout Questionnaire (ABQ). European Journal of Psychological Assessment, 26(3), 203-211.

Jowett, G. E., Hill, A. P., Hall, H. K., \& Curran, T. (2016). Perfectionism, Burnout and Engagement in Youth Sport: The Mediating Role of Basic Psychological Needs. Psychology of Sport and Exercise, 24, 18-26.

Kamimura, A., Kawata, Y., Raedeke, T. D., \& Hirosawa, M. (2020). Association of Athlete Burnout with Depression Among Japanese University Athletes. Juntendo Medical Journal, 66(3), 1-12. doi: 10.14789/jmj.2020.66.JMJ19-OA24

Kovács K., Gyömbér N., F. Földi R., \& Lénárt Á. (megjelenés alatt). Észlelt Autonómia Támogatás Kérdôívek Hazai Adaptációja, Alkalmazott Pszichológia.

Lonsdale, C., Hodge, K., \& Rose, E. (2009). Athlete burnout in elite sport: A self-determination perspective. Journal of Sports Sciences, 27(8), 785-795.

Lundkvist, E., Gustafsson, H., Davis, P. A., Holmström, S., Lemyre, N., \& Ivarsson, A. (2018). The temporal relations across burnout dimensions in athletes. Scandinavian Journal of Medicine \& Science in Sports, 28(3), 1215-1226.

Martínez-Alvarado, J. R., Guillén García, F., \& Feltz, D. (2016). Athletes’ Motivational Needs Regarding Burnout and Engagement. Revista de Psicologia del Deporte, 25(1), 65-71.

Martínez-Alvarado, J. R., Guillén, F., Palacios, L. H. A., Magallanes, A. G., Ruíz, P. F., \& Asadi, A. A. (2019). Analysis of The Psychometric Properties of the Athlete Burnout Questionnaire (ABQ) in Mexican Athletes. Anales de Psicología, 35(2), 341-349.

Maslach, C., \& Jackson, S. E. (1984). Patterns of Burnout among a National Sample of Public Contact Workers. Journal of Health and Human Resources Administration, 7(2), 189-212.

Maslach, C., Jackson, S. E., Leiter, M. P., Schaufeli, W. B., \& Schwab, R. L. (1986). Maslach Burnout Inventory Manual. Palo Alto, CA: Consulting Psychologists Press.

Pacewicz, C. E., Gotwals, J. K., \& Blanton, J. E. (2018). Perfectionism, Coping, and Burnout among Intercollegiate Varsity Athletes: A Person-Oriented Investigation of Group Differences and Mediation. Psychology of Sport and Exercise, 35, 207-217.

Pelletier, L. G., Rocchi, M. A., Vallerand, R. J., Deci, E. L., \& Ryan, R. M. (2013). Validation of the revised sport motivation scale (SMS-II). Psychology of Sport and Exercise, 14(3), 329-341.

Raedeke, T. (1997). Is Athlete Burnout More than Just Stress? A Sport Commitment Perspective. Journal of Sport and Exercise Psychology, 19(4), 396-417.

Raedeke, T. D., \& Smith, A. (2001). Development and Preliminary Validation of an Athlete Burnout Measure. Journal of Sport and Exercise Psychology, 23, 281-306.

Reinhardt, M., Tóth, L., \& Rice, K. G. (2019). Perfekcionista csoportok pozitív mentális egészsége - a perfekcionizmus, az érzelemszabályozás és a szubjektív jóllét mintázódása fiatal élsportolók körében. Magyar Pszichológiai Szemle, 74(3), 301-325.

Russell, W., \& Molina, S. (2018). A Comparison of Female Youth Sport Specializers and NonSpecializers on Sport Motivation and Athletic Burnout. Journal of Sport Behavior, 41(3), 330350.

Silva, J. M. (1990). An analysis of the training stress syndrome in competitive athletics. Journal of Applied Sport Psychology, 2(1), 5-20.

Smith, R. E. (1986). Toward a Cognitive-Affective Model of Athletic Burnout. Journal of Sport and Exercise Psychology, 8(1), 36-50.

Schmidt, G. W., \& Stein, G. L. (1991). Sport commitment: A model integrating enjoyment, dropout, and burnout. Journal of Sport and Exercise Psychology, 13(3), 254-265.

Smohai, M., Szemes, Á., Bernhardt-Torma, N., Mirnics, Zs., Bóna, K., Kovács, K., Gyömbér, N., Béres, R., \& Tóth, L. (2019). Psychometric properties of the Hungarian adaptation of the Sport Motivation Scale II. Kézirat. 
Tenenbaum, G., Jones, C. M., Kitsantas, A., Sacks, D. N., \& Berwick, J. P. (2003). Failure Adaptation: An Investigation of the Stress Response Process in Sport. International Journal of Sport Psychology, 34(1), 27-62.

Vealey, R. S., Armstrong, L., Comar, W., \& Greenleaf, C. A. (1998). Influence of Perceived Coaching Behaviors on Burnout and Competitive Anxiety in Female College Athletes. Journal of Applied Sport Psychology, 10(2), 297-318.

\title{
ADAPTATION OF ATHLETIC BURNOUT QUESTIONNAIRE IN A HUNGARIAN SAMPLE OF ATHLETES
}

\author{
KOVÁCS, KRISZTINA - BERKI, TAMÁS - ÁGOSTON, RÉKA - SMOHAI, MÁTÉ - \\ HARSÁNYI, SZABOLCS GERGÖ - SZEMES, ÁGNES - GYÖMBÉR, NOÉMI
}

Background and aims: The goal of this study is to investigate the psychometric characteristics of the Hungarian version of the Athlete Burnout Questionnaire (ABQ, Raedeke and Smith, 2001) and examinate the reliability and validity of this questionnaire.

Methods: 1317 athletes were involved in this study (mean age =20,45; SD = 4,39; men =649; women = 669). Beside the above mentioned questionnaire (ABQ-H), the Sport Climate Questionnaire (SCQ-H; Deci, 2001; Kovács, Gyömbér, F. Földi, Ẽ Lénárt, in press), the Sport Motivation Scale -2 (SMS-2; Smohai et al, 2019) and the Short Almost Perfect Scale (Reinhardt, Toth and Rice, 2019) were applied for the validation.

Results: The confirmatory factor analysis showed consistency with the original structure. We found three, separated factors: reduced sense of accomplishment; emotional and physical exhaustion and devaluation. Internal consistency of the subscales (Cronbach- $\alpha$ : 0,76-0,86) proved to be adequate. Correlation coefficient for test-retest reliability was ranging from 0,60 to 0,92 (Exhaustion $-r(121)=0,92, p<0.001$; Devaluation $-r(123)=0,90, p<0,001$; Reduced sense of accomplishment $-r(123)=0,60, p<0,001)$. Examination of convergent validity revealed small relationships $(r=-0,20-0,52)-$ as it was found in the literature too - among the three scales of athletic burnout, the types of sportmotivation, the level of the perceived autonomy support from coach and the forms of perfectionism.

Discussion: The Hungarian version of the $A B Q$ seems to be a valid and reliable questionnaire to measure, among adolescent athletes particularly.

Keywords: athletic burnout, autonomy support, self-determination theory, perfectionism

A cikk a Creative Commons Attribution 4.0 International License (https://creativecommons. org/licenses/by/4.0) feltételei szerint publikált Open Access közlemény, melynek szellemében a cikk bármilyen médiumban szabadon felhasználható, megosztható és újraközölhetô, feltéve, hogy az eredeti szerzô és a közlés helye, illetve a CC License linkje és az esetlegesen végrehajtott módosítások feltüntetésre kerülnek. (SID_1) 


\section{MELLÉKLET}

\section{Sportolói Kiégés Kérdőív - ABQ}

Ez a kérdőív 15 állítást tartalmaz, amelyek a sporttal kapcsolatos érzésekre vonatkoznak. Kérjük, olvasd el az egyes állításokat és jelöld meg válaszod az alábbiak szerint:

Ha úgy gondolod, hogy az adott érzést szinte soha nem tapasztalod, akkor az 1-est karikázd be. Ha ritkán, akkor a 2-est, ha néha, akkor a 3-ast. Ha gyakran tapasztalod az adott érzést, akkor a 4-est karikázd be, ha pedig szinte állandóan, akkor az 5-öst.

Kérjük, hogy minden kérdésre válaszolj, nincsenek helyes vagy helytelen megoldások. Válaszolj úgy, hogy válaszaid a téged legpontosabban jellemzó képet tükrözzék. Ne gondolkodj sokat, hallgass a legelsô megérzésedre!

\begin{tabular}{|l|l|c|c|c|c|c|}
\hline 1 & Úgy érzem, érdemleges teljesítményt érek el a sportban. & 1 & 2 & 3 & 4 & 5 \\
\hline 2 & $\begin{array}{l}\text { Annyira fáradtnak érzem magam az edzéstől, hogy nehezen } \\
\text { találok energiát más dolgokra. }\end{array}$ & 1 & 2 & 3 & 4 & 5 \\
\hline 3 & $\begin{array}{l}\text { Az erôfeszítéseket, amelyeket a sportágamra fordítok, jobb } \\
\text { lenne, ha másra fordítanám. }\end{array}$ & 1 & 2 & 3 & 4 & 5 \\
\hline 4 & Túlságosan fáradtnak érzem magam a sportolástól. & 1 & 2 & 3 & 4 & 5 \\
\hline 5 & Úgy érzem, nem teljesítek túl jól a sportban. & 1 & 2 & 3 & 4 & 5 \\
\hline 6 & $\begin{array}{l}\text { Nem törốdöm már annyira a sportteljesítményemmel, mint } \\
\text { régebben. }\end{array}$ & 1 & 2 & 3 & 4 & 5 \\
\hline 7 & Úgy érzem, nem teljesítek a képességeimnek megfelelóen. & 1 & 2 & 3 & 4 & 5 \\
\hline 8 & Holtfáradtnak érzem magam a sportolástól. & 1 & 2 & 3 & 4 & 5 \\
\hline 9 & Nem kedvelem már annyira a sportágamat, mint régen. & 1 & 2 & 3 & 4 & 5 \\
\hline 10 & Úgy érzem, fizikailag ki vagyok merülve a sporttól. & 1 & 2 & 3 & 4 & 5 \\
\hline 11 & $\begin{array}{l}\text { Kevésbé aggódom, hogy sikeres legyek a sportban, mint } \\
\text { régebben. }\end{array}$ & 1 & 2 & 3 & 4 & 5 \\
\hline 12 & Kimerültem a sport mentális és fizikai követelményeitốl. & 1 & 2 & 3 & 4 & 5 \\
\hline 13 & $\begin{array}{l}\text { Úgy túnik, mindegy, mit csinálok, nem teljesítek annyira jól, } \\
\text { mint kellene. }\end{array}$ & 1 & 2 & 3 & 4 & 5 \\
\hline 14 & Sikeresnek érzem magam a sportágamban. & 1 & 2 & 3 & 4 & 5 \\
\hline 15 & Negatív érzéseim vannak a sportágam iránt. & 1 & 2 & 3 & 4 & 5 \\
\hline
\end{tabular}

\section{Kiértékelés}

Az alskálaképzés a hozzájuk tartozó tételek összeadásával történik.

Teljesítmény csökkenésének érzete alskála: 1 (fordított), 5, 7, 13, 14 (fordított)

Érzelmi és fizikai kimerültség alskála: 2, 4, 8, 10, 12

Leértékelés alskála: 3, 6, 9, 11, 15 